\title{
Paleomagnetism of the Silurian-Devonian Andreas redbeds: Evidence for an Early Devonian supercontinent?
}

\author{
John D. Miller, Dennis V. Kent \\ Lamont-Doherty Geological Observatory and Department of Geological Sciences \\ Columbia University, Palisades, New York 10964
}

\begin{abstract}
Two components of magnetization were isolated in the SilurianDevonian Andreas redbeds of the central Appalachians of Pennsylvania (lat $40.75^{\circ} \mathrm{N}$, long $75.78^{\circ} \mathrm{W}$ ): a thermally distributed, synfolding B component, and a thermally discrete, pre-Alleghenian-age folding $\mathbf{C}$ component. The $\mathrm{C}$ component mean direction and associated pole position correspond to a Silurian-Devonian paleolatitude for the Andreas location of about $35^{\circ} \mathrm{S}$, which, in conjunction with Early Devonian results from Gondwana, is consistent with an Early Devonian supercontinent configuration.
\end{abstract}

\section{INTRODUCTION}

The paleomagnetic pole position for cratonic North America for latest Silurian to Early Devonian time is currently documented only by data from the Lower Devonian Peel Sound redbeds of the Canadian Arctic (Dankers, 1982). The multicomponent Peel Sound magnetizations correspond to Danker's MDL pole, which was present at most sites and was presumed to represent the Early Devonian cratonic pole position, and his $\mathrm{E}$ pole, which was isolated at only one site and was presumed to represent a later (Late Devonian) remagnetization. However, the lack of a fold test in the Peel Sound study precluded more definitive relative age control on the MDL and $\mathrm{E}$ pole magnetizations.

It had been suggested, largely on the basis of faunal affinities, that there was a supercontinent configuration of Laurentia and Gondwana in the Early to Middle Devonian and that the Acadian orogeny was the result of a collision between northeastern North America and northwestern South America (McKerrow and Ziegler, 1972; Keppie, 1977). More recent interpretations (e.g., Scotese, 1984), based largely on the paleomag-

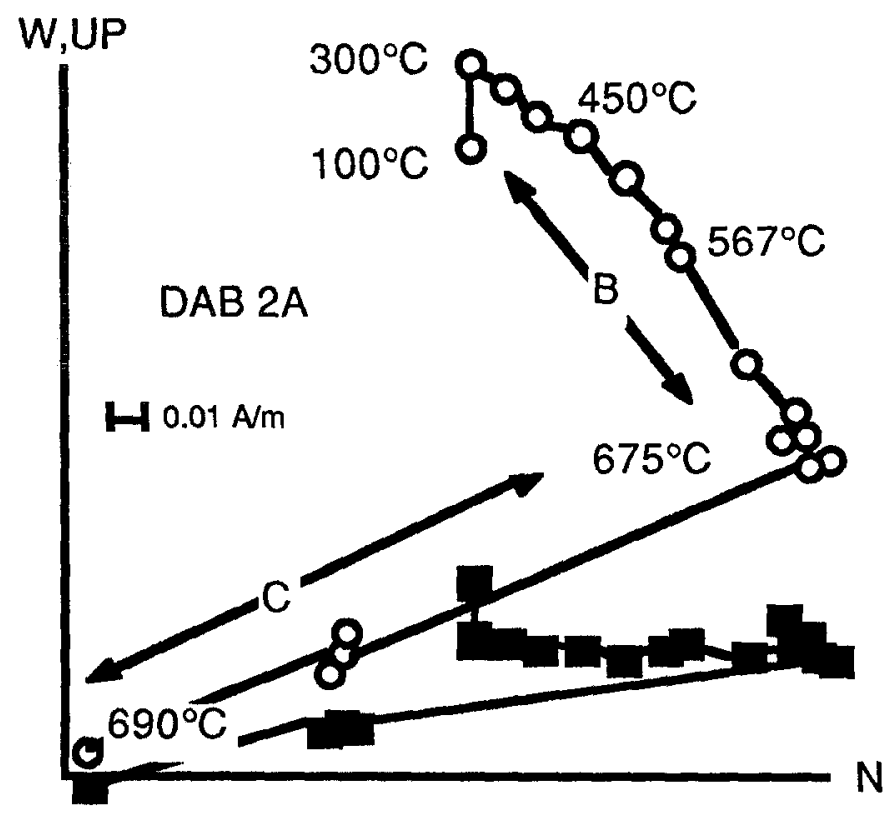

Figure 1. Representative Zijderveld demagnetogram plotted in geographic coordinates. Open symbols are projections in vertical plane. Solid symbols are projections in horizonfal plane. netic data from the Peel Sound Formation, suggest a wide ocean between Laurentia and Gondwana in Silurian-Devonian time.

The Upper Silurian-Lower Devonian Andreas redbeds are unique in that they are the only Silurian-Devonian redbeds exposed in the folded Appalachians. Because the more common Silurian-Devonian carbonates were uniformly remagnetized in the late Paleozoic (McCabe et al., 1983), the Andreas redbeds provide an important opportunity to document a Silurian-Devonian paleomagnetic paleopole for North America.

\section{GEOLOGIC SETTING}

The Andreas redbeds (Swartz and Swartz, 1941) are a thin $(\sim 20 \mathrm{~m}$ thick) sandstone unit. The unit lacks a distinctive fossil assemblage but is constrained to be Upper Silurian or Lower Devonian by the conodont, ostracod, brachiopod, and bryozoan biostratigraphy of the stratigraphically underlying Pridolian (Denkler, 1984) Keyser Limestone and the overlying Gedinnian (Epstein et al., 1967) Coeymans Limestone.

We sampled the Andreas redbeds at the large road-metal quarry near Andreas, Pennsylvania, where we had access to both limbs of a small (few hundred metres wavelength) nonplunging Alleghenian (Carboniferous to Permian) anticline. Standard paleomagnetic techniques were used in the field and laboratory (see Miller and Kent, 1986b for details).

\section{PALEOMAGNETIC RESULTS}

Progressive thermal demagnetization reveals that the natural remanent magnetizations (NRM) of samples from the Andreas redbeds are typically composed of two components (Fig. 1). Between $300^{\circ} \mathrm{C}$ and about $675^{\circ} \mathrm{C}$, a south-southeast (in all but three samples) component of NRM (labeled B in Fig. 1) was unblocked which in most samples did not trend toward the origin (Table 1; Figs. 1, 2). Above $675^{\circ} \mathrm{C}$, a final northerly (one southerly sample) component of NRM (labeled C in Fig. 1) was unblocked which decayed to the origin. Isolation of the $\mathrm{C}$ component was hindered in some samples because of magnetochemical alteration. The high $\left(>600^{\circ} \mathrm{C}\right)$ unblocking temperatures of the $\mathrm{B}$ and $\mathrm{C}$ components suggest hematite as the magnetic carrier for both these magnetizations.

Because of the limited availability of outcrop, only two sites with independent bedding attitudes (DAA and DAB) were sampled. At the sample statistical level, the B component Fisherian precision parameter, $k$, reaches a peak value at about half-way through bedding tilt correction (TC; Table 1 , Fig. 2). This peak value of $k$ (29 at $50 \%$ TC) is significantly different from the $k$ values at $0 \%$ TC (10) and $100 \%$ TC (10) at the $99 \%$ confidence limit (Watson, 1956). The McFadden and Lowes (1981) test for discrimination of mean directions was used to provide a site level incremental fold test. The B component site level statistics confirm the sample level statistics in that the mean directions from the two sites are significantly different at both $0 \%$ TC and 100\% TC but cannot be discriminated at high confidence levels near $50 \% \mathrm{TC}\left(\right.$ declination $=170.4^{\circ}$, inclination $=-19.1^{\circ}, \alpha_{95}=5.0^{\circ}$; Table 1).

The sample $\mathrm{C}$ components of magnetization obtain their best grouping at near full tilt correction $\left(357.6^{\circ},-53.3^{\circ}, 8.5^{\circ}\right.$; Fig. 2). Although the $k$ value decreases from $80 \% \mathrm{TC}(15)$ to $100 \% \mathrm{TC}(13)$, these $k$ values are not different at the $95 \%$ confidence limit. The site statistical level discrimination data show that at $0 \% \mathrm{TC}$ the null hypothesis can be rejected at greater than $99 \%$ confidence. The rejection confidence level drops significantly near $80 \%$ TC and then rises to a surprisingly high $94 \%$ at $100 \%$ TC. 
The significant peak in $k$ at 50\% TC suggests either that the B component was acquired during folding or that it was acquired prior to folding and subsequently modified by strain during deformation (e.g., van der Pluijm, 1987). Because the B component pole position plots on the Permian part of the North American apparent polar wander path (NAAPWP; Fig. 3), similar to other observed Appalachian redbed remagnetizations (e.g., Kent and Opdyke, 1985; Miller and Kent, 1986a, 1986b), the simplest interpretation at this time is that the B component in the Andreas redbeds is a secondary magnetization, acquired around the time of Alleghenian folding. The high unblocking temperature of the B component and the low metamorphic grade in the Andreas area suggests that the B component was acquired through chemical, rather than thermoviscous, activation (Kent and Miller, 1987).

The C magnetization passes the fold test at the $99 \%$ confidence level

TABLE 1._SITE DIRECIIONS AND STATISTICS

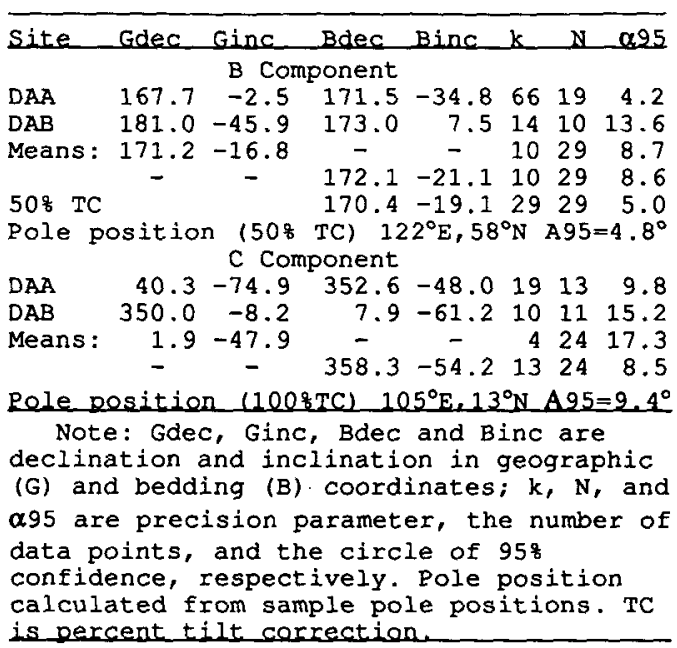

at the sample statistical level; at the site statistical level, the null hypothesis that the site mean directions from opposite fold limbs are the same at $100 \%$ TC cannot be rejected with $95 \%$ confidence. We therefore interpret these statistics to indicate that the $\mathrm{C}$ magnetization predates the CarboniferousPermian folding. The observation that the Andreas $\mathrm{C}$ magnetization is not similar to any magnetization direction that would be predicted for the Andreas locality from the known Late Devonian through Carboniferous NAAPWP suggests a Late Silurian to Middle Devonian acquisition age. The improved grouping at $80 \%$ TC may suggest either that the C component was acquired during a very early stage of deformation (Early to Middle Devonian or Acadian?) or that the C component has suffered some minor effects of strain. The discrimination of these two interpretations will require better understanding of the possibilities of Acadian deformation in the central Appalachians and of the nature and effects of strain in the redbeds exposed in the Valley and Ridge province. For the following discussion, the $\mathrm{C}$ magnetization is presumed to have been acquired near the time of deposition at around the Silurian-Devonian boundary. A slightly younger magnetization age or small directional deviation due to strain will not strongly affect the tectonic implications of these data.

\section{COMPARISON WITH NORTH AMERICAN CRATONIC RESULTS}

The $C$ magnetization pole (lat $105^{\circ} \mathrm{E}$, long $13^{\circ} \mathrm{N}, \alpha_{95}=9.4^{\circ}$ ) does not overlap at the $95 \%$ confidence level with either the MDL pole or the $E$ pole (Fig. 3) reported from the Peel Sound Formation in the Canadian Arctic (Dankers, 1982). The position of the MDL pole between the Andreas pole and the pole from the Upper Devonian Catskill Formation from the northern limb of the Pennsylvania salient (Miller and Kent, 1986a) suggests that, contrary to the original interpretation, the MDL magnetization is Middle to Late Devonian in age and thus represents a remagnetization. The E pole magnetization may represent an Early Devonian magnetization, but its significance is difficult to assess because it is based on data from only one site.
Figure 2. Left: Results of incremental fold test for $B$ and $C$ components at site and sample hierarchical levels. $C L$ represents confidence levels at which null hypothesis that mean directions from two limbs of fold are same can be rejected (McFadden and Lowes, 1981); $k$ is sample group precision parameter. Right: Stereographic projections of isolated sample component directions. Open and solid symbols are projections on upper and lower hemispheres, respectively.

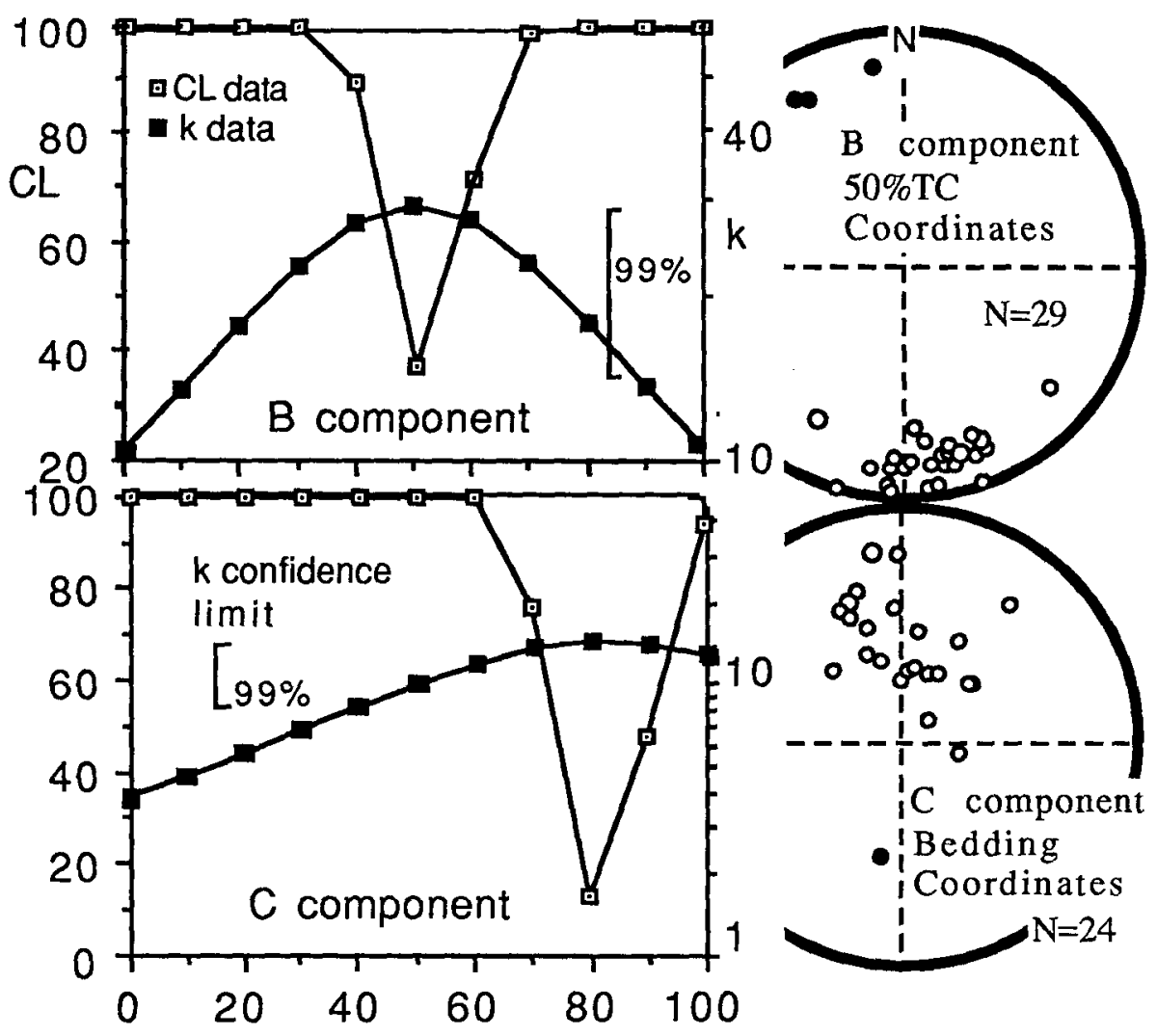


Recent paleomagnetic results suggest that oroclinal rotation may have been involved in the formation of the Pennsylvania salient (Kent and Opdyke, 1985; Miller and Kent, 1986b). The Andreas redbeds crop out on the northern limb of the salient and therefore may have been rotated up to $20^{\circ}$ clockwise relative to the craton since deposition. Such a rotation would cause an error in the paleoazimuthal, but not the paleolatitudinal, determination of the paleogeography of North America and should be considered in any tectonic interpretation involving the Andreas $C$ component. It is interesting to note that the sense of rotation observed in the data from the salient would shift the Andreas pole even farther from the MDL and E poles (Fig. 3).

\section{PALEOGEOGRAPHIC IMPLICATIONS}

In the Ordovician, North America occupied low paleolatitudes while Avalon and Gondwana occupied high southern paleolatitudes (R. Van der Voo, 1988). Revised results from North America show little if any latitudinal displacement between North America and northern Avalon in the Late Devonian (Miller and Kent, 1986a). Therefore, collision of North America and Avalon must have occurred between these two time periods.

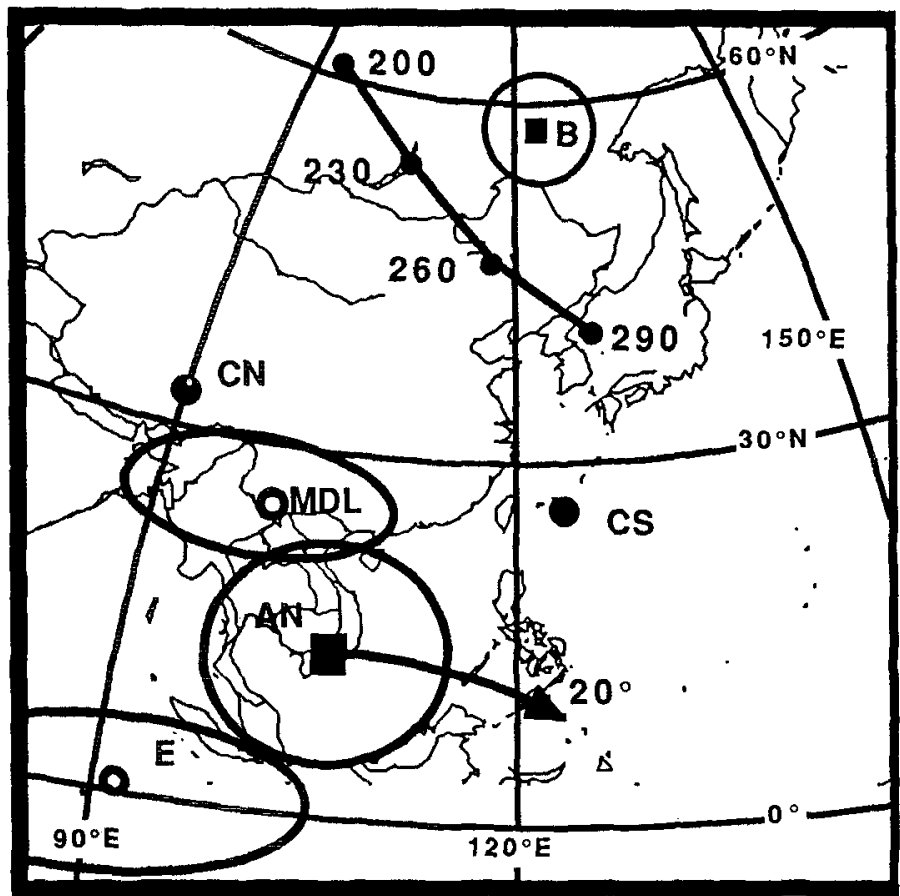

Figure 3. Numbered points are average ages (Ma) of North American apparent polar wander paths trom Irving and Irving (1982). CN and CS are poles from Late Devonian Catskill redbeds from northern $(N)$ and southern (S) limbs of Pennsylvanian salient (Miller and Kent, 1986a, 1986b). MDL and E are poles from Early Devonian Peel Sound Formation (Dankers, 1982). AN and $B$ are $C$ and $B$ component poles from Andreas redbeds, respectively (this study). Arrow indicates motion of AN that would be required to correct for $20^{\circ}$ of clockwise oroclinal rotation of Andreas site. Confidence envelopes are calculated at $95 \%$ level.

Figure 4. Silurian-Devonian paleogeography inferred by positioning Euramerica (Bullard et al., 1965 fii) by Andreas pole position (this study) and Gondwana (Smith and Hallam, 1970 fit) by Snowy River pole (Schmidt et al., 1987). Silurian-Devonian observed paleolatitudes from Baltica (A: Douglass, in prep.), Britain (B: Torsvik, 1985), Armorica (C: Perroud and Bonhommet, 1984), and Avalon (D: Lapointe, 1979; Kent and Opdyke, 1980) are consistent with such reconstruction. Late Devonian paleogeography: Euramerica is positioned in accordance with Catskill results (Miller and Kent, 1986a, 1986b; midpoint of two poles used), and Gondwana is positioned by Canning Basin pole (Hurley and Van der Voo, 1987).
Early Devonian poles from northern Avalon show much scatter; however, comparison of some mutually consistent results from Avalon (Fig. 4) with the Andreas prefolding component suggests that there was little paleomagnetically resolvable offset between Avalon and North America during the Devonian. Furthermore, the general agreement of paleolatitudes observed from Early Devonian age rocks from Baltica and Armorica with the paleolatitudinal grid suggested by the Andreas pole is consistent with the assertion that Euramerica was basically assembled by the Early Devonian (Van der Voo, 1982).

Positioning Euramerica according to the Andreas result places the east coast of North America in the paleolatitude band of $30^{\circ} \mathrm{S}$ to $40^{\circ} \mathrm{S}$ (Fig. 4), slightly farther south than the $30^{\circ} \mathrm{S}$ suggested by paleomagnetic resuits from the Middle to Late Silurian Wabash Limestone (McCabe et
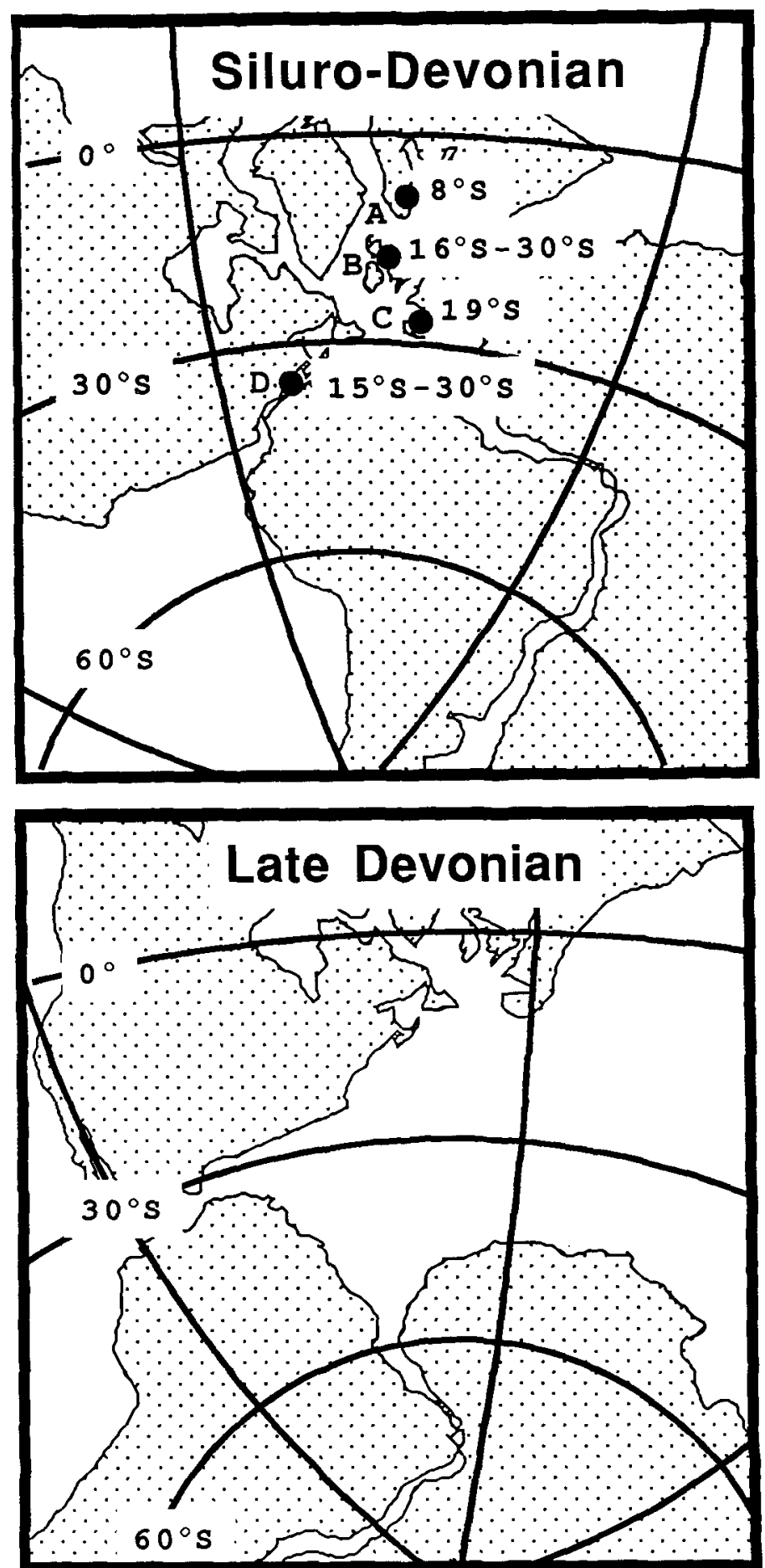
al., 1985). If Gondwana is positioned by the Lower Devonian Snowy River Volcanics pole from Australia (Schmidt et al., 1987), then the northwestern margin of South America occupies a similar paleolatitudinal position.

The best-fitting paleolatitudinal positions for North America and South America suggested by the Andreas and Snowy River pole positions allow a supercontinent configuration that is virtually identical to those proposed by McKerrow and Ziegler (1972) and Keppie (1977), which are based largely on faunal distributions. These authors suggested that the Acadian orogeny resulted from the collision between North America and South America; Avalon was sandwiched between. Dominantly rightlateral motion between Euramerica and Gondwana during the Devonian was required to open an ocean between the two landmasses and to obtain the Late Devonian configuration (Fig. 4), from which the CarboniferousPermian Pangea could form.

Interpretation of current paleomagnetic evidence is somewhat divided concerning the pre-Acadian orogeny location of Avalon. One major modification must be made to the McKerrow and Ziegler model; i.e., Avalon should no longer be viewed as a promontory of Baltica, but rather as part of Gondwana (Van der Voo and Johnson, 1985). The steep inclinations indicative of southerly paleolatitudes near $75^{\circ} \mathrm{S}$ observed in Ordovician rocks from the Delaware Piedmont part of Avalon are most consistent with placement of the Piedmont on the northern margin of Africa, thus requiring westward transport of the Piedmont for it to be involved in a North America-South America continent/continent collision (R. Van der Voo, 1988). However, Late Ordovician results from the Dunn Point Formation of Nova Scotia reveal a more northerly paleolatitude ( $42^{\circ} \mathrm{S}$; Van der Voo and Johnson, 1985), which permits placement of the northern part of Avalon near northwestern South America, consistent with the McKerrow and Ziegler (1972) and Keppie (1977) models for the Acadian orogeny.

\section{CONCLUSIONS}

The paleolatitude associated with the Andreas prefolding $C$ magnetization suggests that North America was located farther south than previously thought and supports the hypothesis of a tectonic linkage between North America and South America in the Early Devonian. We do not mean to imply that the Andreas result provides conclusive proof of the McKerrow and Ziegler (1972) and Keppie (1977) reconstructions. There could have been any amount of undetectable longitudinal offset between the Americas at this time and the paleolatitudinal uncertainty inherent in the data allow more Pangealike reconstructions such as proposed by Boucot and Gray (1983) and Hargraves et al. (1987). However, the Andreas result, and the best-fitting reconstructions it suggests, provide impetus for further research and discussion concerning the possibility, configuration, and implications of an Early Devonian supercontinent.

\section{REFERENCES CITED}

Boucot, A.J., and Gray, J., 1983, A Paleozoic Pangea: Science, v. 222, p. 571-580

Bullard, E.C., Everett, J.E., and Smith, A.G., 1965, A symposium on continenta drift IV: The fit of the continents around the Atlantic: Royal Society of London Philosophical Transactions, ser. A, v. 258, p. 41-51.

Dankers, P., 1982, Implications of Early Devonian poles from the Canadian Arctic Archipelago for the North American apparent polar wander path: Canadian Journal of Earth Sciences, v. 19, p. 1802-1809.

Denkler, K.E., 1984, Upper Silurian biostratigraphy of the Andreas Quarry, Pennsylvania, in Lash, G.G., Lyttle, P.T., and Epstein, J.B., eds., Guidebook for the 49th annual field conference of Pennsylvania geologists: Harrisburg, Pennsylvania, Bureau of Topographic and Geologic Survey, p. 11-20.

Epstein, A.G., Epstein, J.B., Spink, W.J., and Jennings, D.S., 1967, Upper Silurian and Lower Devonian stratigraphy of northeastern Pennsylvania, New Jersey, and southeasternmost New York: U.S. Geological Survey Bulletin 1243, 74 p.

Hargraves, R.B., Dawson, E.M., and Van Houten, F.B., 1987, Paleomagnetism and age of mid-Paleozoic ring complexes in Niger, West Africa, and tectonic implications: Royal Astronomical Society Geophysical Journal, v. 90 p. 705-729.
Hurley, N.F., and Van der Voo, R., 1987, Paleomagnetism of Upper Devonian reefal limestones, Canning Basin, Western Australia: Geological Society of America Bulletin, v. 98, p. 138-146.

Irving, E., and Irving, G.A., 1982, Apparent polar wander paths, Carboniferous through Cenozoic and the assembly of Gondwana: Geophysical Surveys, v. 5, p. 141-188.

Kent, D.V., and Miller, J.D., 1987, Redbeds and thermoviscous magnetization theory: Geophysical Research Letters, v. 13, p. 327-330.

Kent, D.V., and Opdyke, N.D., 1980, Paleomagnetism of Silurian-Devonian rocks from eastern Maine: Canadian Journal of Earth Sciences, v. 17, p. 1653-1665.

_ 1985, Multicomponent magnetizations from the Mississippi Mauch Chunk Formation of the central Appalachians and their tectonic implications: Journal of Geophysical Research, v. 90, p. 5371-5383.

Keppie, J.D., 1977, Plate tectonic interpretation of Paleozoic world maps: Nova Scotia Department of Mines, Paper 77-3, p. 75.

Lapointe, P., 1979, Paleomagnetism and orogenic history of the Botwood Group and Mt Peyton Batholith, Central Mobile Belt, Newfoundland: Canadian Journal of Earth Sciences, v. 16, p. 866-876.

McCabe, C., Van der Voo, R., Peacor, D.R., Scotese, C.R., and Freeman, R., 1983, Diagenetic magnetite carries ancient yet secondary remanence in some Paleozoic sedimentary carbonates: Geology, v. 11, p. 221-223.

McCabe, C., Van der Voo, R., Wilkinson, B.H., and Devaney, K., 1985, A Middle/Late Silurian paleomagnetic pole from limestone reefs of the Wabash Formation, Indiana, USA: Journal of Geophysical Research, v. 90, p. 2959-2965.

McFadden, P.L., and Lowes, F.J., 1981, The discrimination of mean directions drawn from Fisher distributions: Royal Astronomical Society Geophysical Journal, v. 67, p. 19-33.

McKerrow, W.S., and Ziegler, A.M., 1972, Paleozoic oceans: Nature, v. 240, p. 92-94.

Miller, J.D., and Kent, D.V., 1986a, Synfolding and prefolding magnetizations in the Upper Devonian Catskill Formation of eastern Pennsylvania: Journal of Geophysical Research, v. 91, p. 12791-12803.

_ 1986b, Paleomagnetism of the Upper Devonian Catskill Formation from the southern limb of the Pennsylvania salient: Geophysical Research Letters, v. 13, p. 1173-1176.

Perroud, H., and Bonhommet, N., 1984, A Devonian paleomagnetic pole for Armorica: Royal Astronomical Society Geophysical Journal, v. 77, p. 839-845.

Schmidt, P.W., Embleton, B.J.J., and Palmer, H.C., 1987, Pre- and post-folding magnetizations from the Early Devonian Snowy River Volcanics and Buchan Caves Limestone, Victoria: Royal Astronomical Society Geophysical Journal, v. 91, p. $155-170$

Scotese, C.R., 1984, An introduction to this volume: Paleozoic paleomagnetism and the assembly of Pangea, in Van der Voo, R., Scotese, C.R., and Bonhommet, N., eds., Plate reconstruction from Paleozoic paleomagnetism: American Geophysical Union Geodynamics Series, v. 12, p. 1-12.

Smith, A.G., and Hallam, A., 1970, The fit of the southern continents: Nature v. 225 , p. $139-144$

Swartz, C.K., and Swartz, F.M., 1941, Early Devonian and Late Silurian formations of southeastern Pennsylvania: Geological Society of America Bulletin, v. 52 , p. $1129-1192$.

Torsvik, T.H., 1985, Magnetic properties of the Lower Old Red Sandstone lavas in the Midland Valley, Scotland: Paleomagnetic and tectonic considerations: Physics of the Earth and Planetary Interiors, v. 39, p. 194-207.

van der Pluijm, B.A., 1987, Grain-scale deformation and the fold test-Evaluation of syn-folding remagnetization: Geophysical Research Letters, v. 14, p. 155-157.

Van der Voo, R., 1982, Pre-Mesozoic paleomagnetism and plate tectonics: Annual Reviews of Earth and Planetary Science, v. 10, p. 191-220.

- 1988, Paleozoic paleography of North America, Gondwana, and intervening displaced terranes: Comparisons of paleomagnetism with paleoclimatology and biogeographical patterns: Geological Society of America Bulletin, v. 100, p. 311-324.

Van der Voo, R, and Johnson, R.J, 1985, Paleomagnetism of the Dunn Point Formation (Nova Scotia): High paleolatitudes for the Avalon terrane in the Late Ordovician: Geophysical Research Letters, v. 12, p. 337-340.

Watson, G.S., 1956, Analysis of dispersion on a sphere: Royal Astronomical Society Monthly Notices, Geophysical Supplement, v. 7, p. 153-159.

\section{ACKNOWLEDGMENTS}

Supported by National Science Foundation Grant EAR 85-07046. We thank W. Witte, D. Schneider, and the Geology reviewers for helpful reviews. Lamont Doherty Geological Observatory Contribution 4215.

Manuscript received September 8, 1987

Revised manuscript received October 29, 1987

Manuscript accepted November 10, 1987 